\title{
Maternal Satisfaction about Prenatal and Postnatal Cares in Vaginal and Cesarean Section Delivery at Teaching and Non- teaching Hospitals of Tabriz/ Iran.
}

\author{
Somayyeh Naghizadeh ${ }^{1}$, Sahar Azari ${ }^{1 *}$, Fatemeh Mohammady ${ }^{1}$, \\ Mehdi Ebrahimpour mirza rezaei 2, Fahimeh Sehhati ${ }^{2}$
}

Article History:
Received 2 November 2013
Accepted 1 February 2014
Revised 19 January 2014
Available online 4 February 2014
Keywords:
Cesarean Section
Postpartum Cares
Satisfaction
Vaginal Delivery
Corresponding Author:
Sahar Azari, MSc in Midwifery,
Department of Midwifery, Tabriz
branch, Islamic Azad University,
Tabriz, Iran.
Tel: +989148667243
Email: azari62@iaut.ac.ir

Article History:

Revised 19 January 2014

Available online 4 February 2014

\section{Keywords:}

Cesarean Section

Postpartum Cares

Satisfaction

Delivery

Corresponding Author:

Sahar Azari, MSc in Midwifery,

Department of Midwifery, Tabriz

Tabriz, Iran.

Email: azari62@iaut.ac.ir

\begin{abstract}
Objectives: The main goal of care services is provide and promote mankind's health. Patient satisfaction is recognized as an important parameter for assessing the quality of patient care services. Spatially mothers' satisfaction from delivery is very important because it influence on family and society psychological health. The aim of this study was comparing maternal satisfaction about prenatal and postnatal cares in vaginal and cesarean section delivery at teaching and nonteaching hospitals of Tabriz/ Iran.

Materials and Methods: This is a descriptive-comparative study. We selected 454 women who had been hospitalized for delivery in Alzahra, Talegani (teaching) and 29Bahman (nonteaching) Tabriz/Iran hospitals. For data collection, we used a questionnaire. Spss/ver13, Descriptive statistic, Independent t test, ANOVA and correlation tests were used for data analysis. Results: Findings indicated the highest level of satisfaction in both kind of hospitals was about physical and the lowest one was about informational aspect in women who had vaginal delivery, accordingly these rates about cesarean section was about physical and about informational and emotional aspects in labor. The analysis of data showed significant difference between mothers' satisfaction with all aspects of care in the teaching and non- teaching hospitals $(\mathrm{P}<0.001)$.

Conclusion: The results showed that the highest rank from mothers' satisfaction was in the physical and the lowest rank was in informational category. Mothers were satisfied from vaginal delivery in all aspects. Rate of satisfaction in nonteaching were more than teaching hospitals.
\end{abstract}

1- Department of Midwifery, Medical Science, Tabriz branch, Islamic Azad University, Tabriz, Iran. 2- Nursing and Midwifery Faculty, Tabriz University of Medical Sciences, Tabriz, Iran. 


\section{Introduction:}

The main goal of care services is provide and promote mankind's health. Whereas most of the maternal and neonatal morbidities and mortalities occur during labor and immediately after delivery, mothers and the neonates as a vulnerable group of society require more attention so that, the prevention of maternal and neonatal death is considered as one of the pillars of social righteousness (1).

Hospitals are responsible for quality assurance programs. Decreasing the patients' waiting time and length of stay, increasing patients and personnel satisfaction are some examples for promotion of performance indexes. personnel-patient relation, personal characteristics, educational level, consider to patient's needs, hospital's location, service waiting time, environmental conditions and food quality are some factors influencing satisfaction in the different hospitals $(2,3)$. It's essential to care and support women perfectly to create a positive feeling toward her delivery experience. Midwifery Cares in the labor room is described in four aspects: 1) Emotional aspect such as, applause, trust and continuous physical presence 2) Informational aspect such as explanation and recommendation 3) Physical aspect which includes providing comfort like giving a massage 4) Women support which includes interpreting and acting on her desires (4). The necessity of patient satisfaction will be acceptable, if we believe human rights and respect the patient/client/care giver as a human (5).

Patient satisfaction is a very important concept in medical care, because the level of patients' satisfaction or dissatisfaction creates different responses to medical services. Satisfied patients mostly accept and follow up the treatment $(6,7)$.

In a study of Maki et al (2006) entitled as "Women's Evaluation of Labor and Delivery Nurses", $90 \%$ of women have assessed their nurses desirable and $10 \%$ of them have considered them undesirable. They evaluate of nurses desirable for their participation (80\%), compliance (76\%), informing
(75\%), encouraging (65\%), and for their attendance (65\%) (8). In Ordibeheshti's study (1998), mother's expectations from delivery care providers were completely achieved in $20 \%$ of cases, were partially achieved in $28 \%$ of cases and were not achieved in $56.2 \%$ of cases (9). In another study from Tehran's University of medical science, Mirmollayi and et al (2008), showed that the majority of mothers were satisfied with all three types of support services (informational, emotional, and physical) which they had received (4).

Pregnancy and delivery are important factors that affect on the maternal and neonatal health. Vaginal delivery in most pregnant women is considered as the best way of delivery, but respect to the great increase in cesarean delivery, caused decreasing the rate. In our country, rate of cesarean section was increased recently. Although this rate was dropped 35\% to 33\% but it is beyond the standards (10). This rate is reported 45.6\% in Tabriz in 2004 (11).

Because the development in caring quality is not achievable without notice to patients' expectations, as well as midwifes have a great role in providing prenatal and postnatal cares, they should be aware of effective factors on this concept.

So the aim of this study was comparing maternal satisfaction about prenatal and postnatal cares in vaginal delivery and cesarean section at teaching and nonteaching hospitals of Tabriz/Iran.

\section{Material \& Methods:}

This study was descriptive-comparative in nature. It was conducted in 2011-2012. The target population consists of 15- 45 years old married women who referred to the teaching (Alzahra, Talegani) and nonteaching (29Bahman) hospitals of Tabriz for delivery. Considering the rate of satisfaction (20\%) with 0.95 confidences and 0.05 error and assuming $10 \%$ of the samples opting out, the initial number of samples was 412 and the final sample size was 454 . At first, the list of all teaching and non- teaching hospitals was provided, and then we used random cluster sampling because of variance rate of delivery in hospitals. In the next step, noting the sample size, 329 cases 
(200 vaginal delivery, 129 cesarean section) among all mothers who were referred for delivery in teaching hospitals and 125 (70 vaginal delivery, 55 cesarean section) in non- teaching. After introducing the study to women who had study's entrance criteria, they were invited to fill out the questionnaires (containing iographical information and patient satisfaction). Sampling was done with random selecting manner in last stage through the using www.randomizer.org website.

Entrance criteria included women being married, who were in 15-45 years old age group and willing to participate in the research, without history of infertility and psychology and physical problems. Also all participants spent at least 2 hours in labor wards. Data was collected by using the questionnaire that has been prepared based on the knowledge of experts. The questionnaire consisted of two parts. The first part contained 9 questions about women's demographic characteristics and obstetric history and the second part was composed of 41 questions which 11 of it was about physical, 12 of it was about informational, 9 of it was about ethical and 9 of it was about emotional aspects of satisfaction. This questionnaire was provided with questions based on a Likert scale of 1 to 5 . For the systematic content analysis, patients' comments in response to specific questions were evaluated and classified as satisfied, extremely satisfied, negative (when explicitly or implicitly indicated dissatisfaction), extremely negative or neutral, lastly changed to satisfied and not satisfied. Then the data were split into two groups, satisfied and not satisfied. Total scores were calculated and presented as percentages. The questionnaires were reviewed by 10 professors of the university to assess content validity, and alpha cronbach coefficient of 0.81 demonstrated reliability of the questionnaire for assessing clients' satisfaction. Statistical analysis of quantitative data was carried out using the statistical package for social sciences (SPSS) software version 13, and descriptive statistics, independent t-test, analysis of variance (ANOVA), and correlation tests were used for data analysis. Mean values (M) and standard deviations (SD), as well as ranges of values were reported.

\section{Results:}

Research was conducted on 454 married women who were referred to delivery. Demographic characteristics of them were given in Table 1 . The average of age was $26.37 \pm 5.51$ years and $1.18 \pm 0.89$ were primypara. The majority of women were housewife, 24 percent had high education and just $77(17 \%)$ of them were ignore (Table 1). The rate of different aspects of satisfaction in the teaching hospitals was shown in Table2. The highest level of satisfaction in both kind of hospitals was about physical and the lowest one was about informational aspect in women who had vaginal delivery, accordingly these rates about cesarean section was about physical and about informational and emotional aspects in labor (Table 2, 3). Difference between teaching and non- teaching hospitals in all aspects in labor phase was statistically meaningful $(\mathrm{p}<0 / 001)$. About the post-partum phase in both kind of hospitals there is statistically meaningful relation between different aspects except physical part $(p=0 / 18)$ with mothers satisfaction (table 4, figure 1,2). There was significant relationship between physical, ethical and emotional aspects of satisfaction with and women's age, education and job $(\mathrm{P}<0.05)$. It was also found that there was no correlation between the number of death and abortion with none of them. (Table5).

\section{Discussion:}

The results of this research showed that, the type of delivery effects the maternal satisfaction in four aspects of caring; which the level of maternal satisfaction from prenatal and postnatal cares of vaginal was more than cesarean delivery.

In women who had a vaginal delivery, dissatisfaction was in informational aspect. In the women with cesarean delivery dissatisfaction was in informational and emotional aspect before delivery and informational and ethical aspects after delivery. Lack of maternal satisfaction from gaining information, can be the result of 
minimizing importance of the role of information and Lack of sufficient time for the patients.

Results of Ordibeheshti's study (1997) showed that in educational maternity hospitals, the maternal informational expectations were not achieved in more than half of cases $(51.10 \%)$, and it was partially achieved in $23.80 \%$ of cases. In this study, the greatest rate of maternal information providence was related to postnatal care information (91\%) and the lowest rate was about the explanation of midwifery and medical expressions, (6\%) and describing the duties of care givers and the other staffs (8\%) (9). the results of this study in the teaching hospitals were the same as Ordibeheshti's study.

The study of Rodman and et al (2007) showed that $33 \%$ of the women were dissatisfied about the cares and the level of dissatisfaction in informational aspect was $7 \%$. Results of study were inconsistent with ours, which can be related to the high quality in information giving in western countries (17).

In this study the greatest rate of dissatisfaction was about emotional aspect, after informational aspect, this lack of satisfaction in cesarean section was more than vaginal delivery.

The results of Corbort and Galister's study emphasized that the clients/care givers in labor needed more emotional supportive behaviors, so that most of them, found supportive behaviors during labor so useful (18). Results of Mirmollayi's study in 2003 showed that the hospitals related to the medical university of Tehran/ Iran, Shahid Beheshti and social security institute, $79.5 \%$ of the mothers are fully satisfied with emotional supports. The results of their study were the same as our study about vaginal delivery, but it was inconsistent with ours about the cesarean delivery (4).

The results of our study show that the results of our study declared that the level of maternal satisfaction from physical care in vaginal and cesarean delivery is more than the other aspects. In study of Ordibeheshti, level of satisfaction from physical care in vaginal delivery was $44.23 \%$ (9). Level of the physical satisfaction, increased considering the study of Ordibeheshti. The possible reasons of difference in these studies were educational development in maternal physical care, the increase in attention toward development in physical care quality and lessened the problems about cares.

In Mirmollayi and et al's study (2008), in hospitals related to the medical university of Tehran, Iran, Shahid Beheshti and social security institute, $68.75 \%$ of mothers had the full satisfaction about the physical support in labor and delivery room (4), which were not the same as this study and the level of it was higher in ours. Environmental, cultural, social and economic difference between samples of our study and Mirmollayi's study can affect the maternal satisfaction directly.

The results of this study show that maternal satisfaction in all of four caring and supportive aspects in non-educational hospitals is significantly higher than educational once, which it can have different reasons. The possible reason of these dissatisfactions is maybe due to the high number of care providers and students in educational hospitals. In the study which Sharami and et al have done, it was indicated that, treat mental hospitals have been more successful than educational hospitals in satisfying of pregnant women in prenatal cares. It may be due to care indexes governing the educational hospitals (19). The results of their study were consistent with ours. In a study based on hospital service quality evaluation and the patients' satisfaction in London, Owusu (2010) showed that the type of the hospital was the main factor in the satisfaction level of women in caring system (20).

\section{Conclusion :}

Since the findings of this study showed that mothers' dissatisfaction rate in noneducational hospitals in which the delivery is made by the midwives under the supervision of women's and labor specialists is higher, it is suggested that in the coming studies, the role of the midwives in attracting the mothers' satisfaction be examined.

Meanwhile, since the current study was done without considering the mother's 
awareness of care standards, it is suggested that a study will be done entitled as "studying the reasons of mothers' dissatisfaction with labor and delivery caretakers before and after receiving the care standards.

\section{Conflicts of interest:}

Authors declare that there is no any conflict of interest.

\section{Acknowledgments:}

I do express my deep appreciation to the head, officials and personnel of the postpartum section of 29Bahman, Alzahraa (S), Taleqani hospitals of Tabriz and the Vice President for Research of Tabriz Medical Sciences University.

Table 1. Personal and obstetrical characteristics of women who referred to the teaching and nonteaching hospitals of Tabriz/Iran for delivery.

\begin{tabular}{|c|c|c|c|c|}
\hline \multicolumn{2}{|c|}{$\begin{array}{c}\text { Hospitals } \\
\text { Characteristics }\end{array}$} & $\begin{array}{l}\text { Teaching } \\
\text { NO. (\%) }\end{array}$ & $\begin{array}{c}\text { Non-teaching } \\
\text { No. (\%) }\end{array}$ & $\begin{array}{c}\text { Total } \\
\text { No. (\%) }\end{array}$ \\
\hline \multirow{5}{*}{ 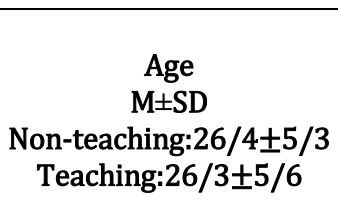 } & $18-23$ & $129(38 / 6)$ & $42(35)$ & \multirow{5}{*}{$454(100)$} \\
\hline & $24-28$ & $87(26)$ & $38(31 / 7)$ & \\
\hline & $29-33$ & $81(24 / 3)$ & $25(20 / 8)$ & \\
\hline & $34-38$ & $30(9)$ & $13(10 / 8)$ & \\
\hline & $39-43$ & $7(2 / 1)$ & $2(1 / 7)$ & \\
\hline \multirow{5}{*}{ Education } & ignore & $55(16 / 5)$ & $22(18 / 3)$ & \multirow{5}{*}{$454(100)$} \\
\hline & primary & $84(25 / 1)$ & $31(25 / 8)$ & \\
\hline & intermediate & $100(29 / 9)$ & $34(28 / 3)$ & \\
\hline & $\begin{array}{l}\text { Diploma of high } \\
\text { school }\end{array}$ & $77(23 / 1)$ & $32(26 / 7)$ & \\
\hline & $\begin{array}{l}\text { University } \\
\text { Degree }\end{array}$ & $18(5 / 4)$ & $1(0 / 8)$ & \\
\hline \multirow[b]{3}{*}{ Job } & Housekeeper & $287(85 / 9)$ & $110(91 / 7)$ & \multirow[b]{3}{*}{$454(100)$} \\
\hline & Work in house & $35(10 / 5)$ & $9(7 / 5)$ & \\
\hline & Work out house & $12(3 / 6)$ & $1(0 / 8)$ & \\
\hline
\end{tabular}


Table 2. Comparing maternal satisfaction about labor and post-partum cares in vaginal delivery and cesarean section in the teaching hospitals of Tabriz/Iran.

\begin{tabular}{|c|c|c|c|c|c|c|c|c|}
\hline & & Satisfaction & $\begin{array}{c}\text { Completely } \\
\text { Satisfied } \\
\text { NO. (\%) }\end{array}$ & $\begin{array}{l}\text { Satisfied } \\
\text { NO. (\%) }\end{array}$ & $\begin{array}{l}\text { neutral } \\
\text { NO. (\%) }\end{array}$ & $\begin{array}{c}\text { Dissatisfie } \\
\text { NO. (\%) }\end{array}$ & $\begin{array}{c}\text { Completely } \\
\text { Dissatisfied } \\
\text { NO. (\%) }\end{array}$ & $\begin{array}{c}\text { Total } \\
\text { NO. (\%) }\end{array}$ \\
\hline \multirow{5}{*}{ labor phase } & \multirow{3}{*}{$\begin{array}{l}\text { vaginal } \\
\text { delivery }\end{array}$} & Physical & $74(37)$ & $113(56 / 5)$ & $11(5 / 5)$ & $2(1)$ & $0(0)$ & $200(100)$ \\
\hline & & Ethical & $82(41)$ & $101(50 / 5)$ & $14(7)$ & $3(1 / 5)$ & $0(0)$ & $200(100)$ \\
\hline & & Emotional & $90(45)$ & $91(45 / 5)$ & $15(7 / 5)$ & $3(1 / 5)$ & $1(0 / 5)$ & $200(100)$ \\
\hline & \multirow{2}{*}{$\begin{array}{l}\text { cesarean } \\
\text { section }\end{array}$} & Ethical & $0(0)$ & $22(16 / 4)$ & $112(83 / 6)$ & $0(0)$ & $0(0)$ & $134(100)$ \\
\hline & & Emotional & $0(0)$ & $102(76 / 1)$ & $32(23 / 9)$ & $0(0)$ & $0(0)$ & $134(100)$ \\
\hline \multirow{5}{*}{$\begin{array}{c}\text { postpartum } \\
\text { phase }\end{array}$} & \multirow{2}{*}{$\begin{array}{l}\text { vaginal } \\
\text { delivery }\end{array}$} & Physical & $35(17 / 5)$ & $108(54)$ & $52(26)$ & $4(2)$ & $1(0 / 5)$ & $200(100)$ \\
\hline & & Informational & $3(1 / 5)$ & $47(23 / 5)$ & $116(58)$ & $25(12 / 5)$ & $6(3)$ & $200(100)$ \\
\hline & \multirow{3}{*}{$\begin{array}{l}\text { cesarean } \\
\text { section }\end{array}$} & Informational & $0(0)$ & $0(0)$ & $0(0)$ & $134(100)$ & $0(0)$ & $134(100)$ \\
\hline & & Ethical & $0(0)$ & $18(13 / 4)$ & $116(86 / 6)$ & $0(0)$ & $0(0)$ & $134(100)$ \\
\hline & & Emotional & $0(0)$ & $8(6)$ & $114(85 / 1)$ & $12(9)$ & $0(0)$ & $134(100)$ \\
\hline
\end{tabular}

Table 3. Comparing maternal satisfaction about labor and post-partum cares in vaginal delivery and cesarean section in the non-teaching hospitals of Tabriz/Iran.

\begin{tabular}{|c|c|c|c|c|c|c|c|c|}
\hline & & Satisfaction & $\begin{array}{c}\text { Completely } \\
\text { Satisfied } \\
\text { NO. (\%) } \\
\end{array}$ & $\begin{array}{l}\text { Satisfied } \\
\text { NO. (\%) }\end{array}$ & $\begin{array}{l}\text { neutral } \\
\text { No. (\%) }\end{array}$ & $\begin{array}{c}\text { Dissatisfie } \\
\text { No. (\%) }\end{array}$ & $\begin{array}{c}\text { Completely } \\
\text { Dissatisfied } \\
\text { NO. (\%) }\end{array}$ & $\begin{array}{c}\text { Total } \\
\text { NO. (\%) }\end{array}$ \\
\hline \multirow{8}{*}{ labor phase } & \multirow{5}{*}{$\begin{array}{l}\text { vaginal } \\
\text { delivery }\end{array}$} & Physical & 21(30) & $43(61 / 4)$ & $6(8 / 6)$ & $0(0)$ & $0(0)$ & $70(100)$ \\
\hline & & Informational & $9(12 / 9)$ & $24(34 / 3)$ & $33(47 / 1)$ & $4(5 / 7)$ & $0(0)$ & $70(100)$ \\
\hline & & Ethical & $35(50)$ & $33(47 / 1)$ & $2(2 / 9)$ & $0(0)$ & $0(0)$ & $70(100)$ \\
\hline & & Emotional & $33(47 / 1)$ & $35(50)$ & $1(1 / 4)$ & $1(1 / 4)$ & $0(0)$ & $70(100)$ \\
\hline & & Physical & $0(0)$ & $46(92)$ & $4(8)$ & $0(0)$ & $0(0)$ & $50(100)$ \\
\hline & \multirow{3}{*}{$\begin{array}{l}\text { cesarean } \\
\text { section }\end{array}$} & Informational & $0(0)$ & $0(0)$ & $50(100)$ & $0(0)$ & $0(0)$ & $50(100)$ \\
\hline & & Ethical & $0(0)$ & $5(10)$ & $45(90)$ & $0(0)$ & $0(0)$ & $50(100)$ \\
\hline & & Emotional & $0(0)$ & $46(92)$ & $4(8)$ & $0(0)$ & $0(0)$ & $50(100)$ \\
\hline \multirow{8}{*}{$\begin{array}{l}\text { postpartum } \\
\text { phase }\end{array}$} & \multirow{4}{*}{$\begin{array}{l}\text { vaginal } \\
\text { delivery }\end{array}$} & Physical & $59(34 / 3)$ & $42(60)$ & $4(5 / 7)$ & $0(0)$ & $0(0)$ & $70(100)$ \\
\hline & & Informational & $19(27 / 1)$ & $33(47 / 1)$ & $17(24 / 3)$ & $1(1 / 4)$ & $0(0)$ & $70(100)$ \\
\hline & & Ethical & $39(55 / 7)$ & $22(31 / 4)$ & $7(10)$ & $2(2 / 9)$ & $0(0)$ & $70(100)$ \\
\hline & & Emotional & $37(52 / 9)$ & $19(27 / 1)$ & $10(14 / 3)$ & $3(4 / 3)$ & $1(1 / 4)$ & $70(100)$ \\
\hline & \multirow{4}{*}{$\begin{array}{l}\text { cesarean } \\
\text { section }\end{array}$} & Physical & $0(0)$ & $6(12)$ & 44(88) & $0(0)$ & $0(0)$ & $50(100)$ \\
\hline & & Informational & $0(0)$ & $1(2)$ & 49(98) & $0(0)$ & $0(0)$ & $50(100)$ \\
\hline & & Ethical & $0(0)$ & $16(32)$ & $34(68)$ & $0(0)$ & $0(0)$ & $50(100)$ \\
\hline & & Emotional & $0(0)$ & $1(2)$ & 44(88) & $4(8)$ & $1(2)$ & $50(100)$ \\
\hline
\end{tabular}


Table 4. comparing of satisfaction rate between teaching and non-teaching hospitals of Tabriz/ Iran.

\begin{tabular}{|c|c|c|c|c|c|}
\hline $\begin{array}{l}\text { Phases of } \\
\text { delivery }\end{array}$ & $\begin{array}{l}\text { Kind of } \\
\text { delivery }\end{array}$ & Satisfaction & $\begin{array}{l}\text { Non-teaching } \\
\text { Mean } \pm S D\end{array}$ & $\begin{array}{l}\text { teaching } \\
\text { Mean } \pm \text { SD }\end{array}$ & P-value \\
\hline labor phase & $\begin{array}{l}\text { vaginal } \\
\text { delivery }\end{array}$ & $\begin{array}{l}\text { Physical } \\
\text { Informational } \\
\text { Ethical } \\
\text { Emotional } \\
\text { Physical } \\
\text { Informational } \\
\text { Ethical } \\
\text { Emotional }\end{array}$ & $\begin{array}{l}44.9 \pm 4.4 \\
46.4 \pm 6.4 \\
37.4 \pm 5.4 \\
31.8 \pm 5.7 \\
35.1 \pm 2.6 \\
28.2 \pm 1.6 \\
29.7 \pm 1.2 \\
22.5 \pm 2.2\end{array}$ & $\begin{array}{c}41 \pm 6.1 \\
37.2 \pm 7.1 \\
32.7 \pm 6.7 \\
26.4 \pm 7.9 \\
35.5 \pm 2.7 \\
28.6 \pm 1 \\
29.3 \pm 1.4 \\
23.1 \pm 2.1\end{array}$ & $\begin{array}{l}\mathrm{P}=0.0001 \\
\mathrm{P}=0.0001 \\
\mathrm{P}=0.0001 \\
\mathrm{P}=0.0001 \\
\mathrm{P}=0.0001 \\
\mathrm{P}=0.0001 \\
\mathrm{P}=0.0001 \\
\mathrm{P}=0.0001\end{array}$ \\
\hline $\begin{array}{l}\text { postpartum } \\
\text { phase }\end{array}$ & $\begin{array}{l}\text { vaginal } \\
\text { delivery }\end{array}$ & $\begin{array}{l}\text { Physical } \\
\text { Informational } \\
\text { Ethical } \\
\text { Emotional } \\
\text { Physical } \\
\text { Informational } \\
\text { Ethical } \\
\text { Emotional }\end{array}$ & $\begin{array}{l}43.8 \pm 4.9 \\
44.5 \pm 7.1 \\
33.4 \pm 3.9 \\
37.1 \pm 4.1 \\
38.5 \pm 0.8 \\
41.1 \pm 1.2 \\
26.7 \pm 1.0 \\
32.4 \pm 1.3\end{array}$ & $\begin{array}{c}44.2 \pm 4.5 \\
40.3 \pm 3.4 \\
32.2 \pm 3.5 \\
31 \pm 1.7 \\
38.8 \pm 1.3 \\
51.8 \pm 3.5 \\
27.1 \pm 1.3 \\
36.9 \pm 4.8\end{array}$ & $\begin{array}{c}P=0.18 \\
P=0.0001 \\
P=0.0001 \\
P=0.0001 \\
P=0.0001 \\
P=0.001 \\
P=0.0001 \\
P=0.0001\end{array}$ \\
\hline
\end{tabular}

Table 5. Association between demographic and obstetrical characteristics and satisfaction with delivery.

\begin{tabular}{c|ccccc}
\hline \multirow{3}{*}{ Characteristics } & Satisfaction & $\begin{array}{c}\text { Physical } \\
\text { p-value }\end{array}$ & $\begin{array}{c}\text { Informational } \\
\text { p-value }\end{array}$ & $\begin{array}{c}\text { Ethical } \\
\text { p-value }\end{array}$ & $\begin{array}{c}\text { Emotional } \\
\text { p-value }\end{array}$ \\
\hline \multirow{3}{*}{ Personal } & $\begin{array}{c}\text { Age } \\
\text { Education } \\
\text { Job }\end{array}$ & $\begin{array}{c}0.0001 \\
0.0001\end{array}$ & $\begin{array}{c}0.01 \\
0.16\end{array}$ & 0.0001 & 0.0001 \\
& & 0.0001 & 0.0001 & 0.001 \\
\cline { 2 - 6 } & $\begin{array}{c}\text { The number of live } \\
\text { children }\end{array}$ & 0.0001 & 0.79 & 0.0001 & 0.0001 \\
\hline \multirow{5}{*}{ obstetrical } & $\begin{array}{c}\text { The number of } \\
\text { dead children }\end{array}$ & 0.41 & 0.8 & 0.24 & 0.63 \\
\cline { 2 - 6 } & $\begin{array}{c}\text { The number of } \\
\text { Abortion }\end{array}$ & 0.58 & 0.89 & 0.99 & 0.25 \\
\hline
\end{tabular}


Figure 1. Comparing maternal satisfaction in vaginal delivery in the non-teaching hospitals of Tabriz/Iran.

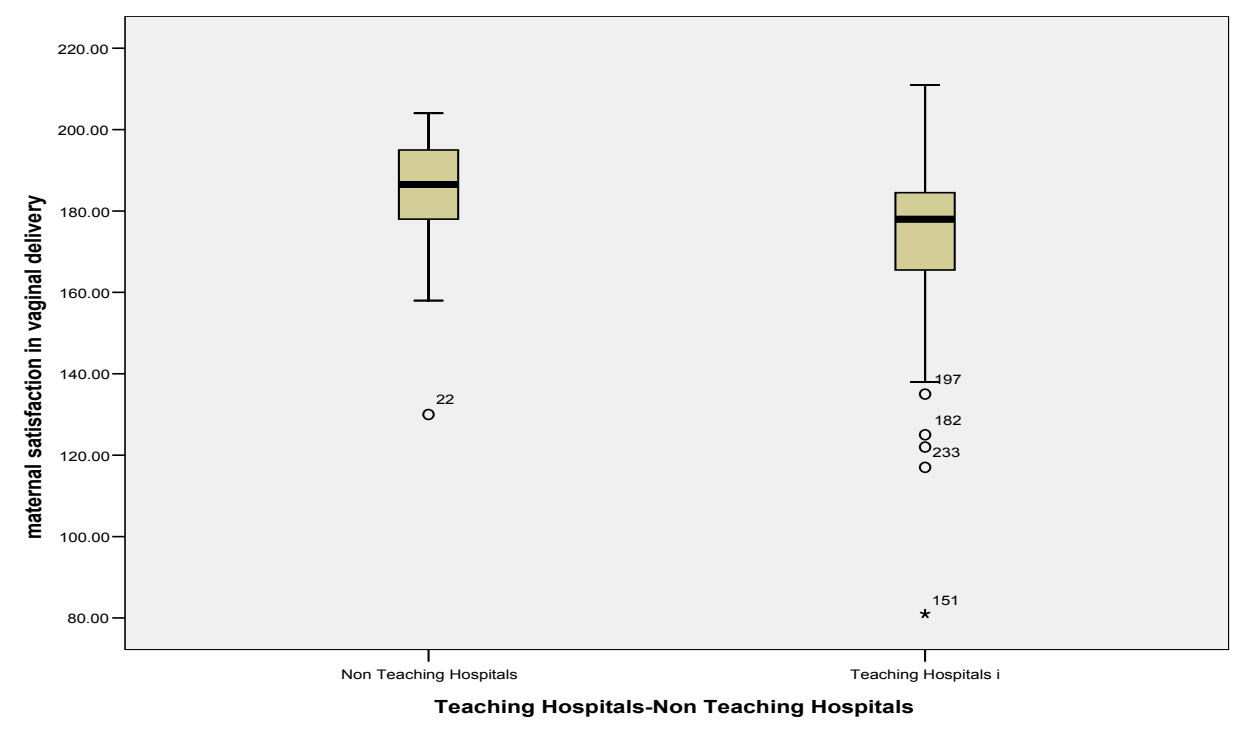

\section{References:}

1. Abedi T. Hospital Administration,1st ed, Tehran: Omidvar Publisher. 2008; 454-66.

2. Arasli H.Gearing service quality into public and private hospitals in small islands. International Journal of Health Care Quality Assurance. 2008; 21(1):8-23.

3. Bacar C, Akgun H. The role of expectations in patient assessments of hospital care. International Journal of Health Care Quality Assurance. 2008; 21(4):343-55.

4. Harvey S, Rach D, Stainton MC, Jarrell J, Brant R. Evaluation of satisfaction with midwifery care. Midwifery. 2002;18(5):260-7.

5. Peterson W. Adolescent mothers 'satisfaction with postpartum nursing care: quantitative and qualitative approaches [dissertation]. Doctor of Philosophy in Nursing: Clinical Health Sciences-Nursing 2004.

6. Simbar M, Alizadeh Dibazari Z, Abed saeidi J, Alava majd H. Assessment of quality of care in postpartum wards of Shaheed Beheshti medical university hospital. Shaheed Beheshti University of Medical Sciences Journal. 2005; 10(43):45-9.

7. Page LA. The new midwifery science and sensitivity in practice. London: Churchill Livingstone. 2000. P.106. 
8. Goodman P, Mackey M.C, Tavakoli A.S. Factors related to childbirth satisfaction. J Adv Nurs. 2004; 46(2):212-9.

9. Mirmolaei ST, Khakbazan Z, Kazemnejad A, Azari M. Prenatal care utilization rate and patient satisfaction. Journal of Faculty of Nursing \& Midwifery Tehran University of Medical Sciences (hayat). 2008; 13(2):31-40.

10. Stephanie Brown BA, Davey MA. Women's Views and Experiences of Postnatal Hospital Care in the Victorian Survey of Recont Mothers. Midwifery. 2005;21(2):109-26.

11. Porheydari M, Sozani A, asaiyan A.view of pregnant women about the way of ending pregnancy.Danash and tandorosti Journal of Shahrod university. 2006; 2(2):28- 34.

12. Mohammadpor A, RostamiI F, Torabi S. Prevalence of Cesarean Section and Its Demographic Correlates in Tabriz Medical journal of Tabriz university of medical science. 2006; 28(3):101-5.

13. Ordibeheshti M. Determine the care of mothers care expectations meeting by care givers of laboring mothers who were admitted to two education and treatment maternity hospital of Tabriz [dissertation]. Master of Science Midwifery: Medical Sciences of Tabriz University, Nursing and Midwifery Faculty1998.

14. Porheydari M, Sozani A, Kasaiyan A. view of pregnant women about the way of ending pregnancy.Danash and tandorosti Journal of Shahrod university. 2006; 2(2): 28-34.

15. Daff La, Lamping D, Ahmed LB. Evaluation satisfaction with maternity care in women from minority ethnic communities: development and validation of a sylheti questionnaire. International Journal Quality in Health Care. 2001; 13(3):215-30.

16. Robledo IJ. The impact of childbirth preparation and support on labor and birth outcome [dissertation]. Doctor of Philosophy in Psychology: university of Rhode Island 1997.

17. Chunuan SK. Patient satisfaction with health care services received during intrapartum in one regional hospital in the southern part of Thailand [dissertation]. Doctor of Philosophy in Nursing: College of Nursing, University of Kentucky 2002.

18. Waldenstrom U, Brown S, McLachlan H, Forster D, Brennecke S. Does team midwife care increase satisfaction with Antenatal, Intrapartum, and postpartum care? A randomized controlled trial. Birth 2000; 27(3):156-67.

19. Rudman A, El-Khouri B, Waldenstrom U. Women's satisfaction with intrapartum care a pattern approach. Journal of Advanced Nursing 2007;59(5):474-487.

20. Sharami SH, Zahiri H, Zendedel S. Assessment the Client satisfaction in Prenatal Unit of Rasht Public Hospitals]. Gilan Uni Med Sc J. 2007; 17(66):29-37. 